\title{
Evaluation of $\mathrm{Cr}(\mathrm{VI})$ Reducing Capability of Shewanella putrefaciens (MTTC8410) and Optimization of Operational Parameters
}

\author{
Annadurai Sakthi Thesai ${ }^{1}$ (D) Rajalingam Sangeetha² ${ }^{\text {(D), }}$ \\ Lakshmanan Ashokkumar $^{1}$ (D) , Ramachandran Palanivelan ${ }^{2}$ (D), \\ Sundaram Rajakumar ${ }^{3}$ (D) and Pudukadu Munusamy Ayyasamy²* (iD \\ ${ }^{1}$ Vivekanandha College of Arts and Sciences for Women, Elayampalayam - 637 205, Tamil Nadu, India. \\ ${ }^{2}$ Department of Microbiology, Periyar University, Salem - 636 011, India. \\ ${ }^{3}$ Department of Marine Biotechnology, Bharathidasan University, Tiruchirappalli- 620024, India.
}

\begin{abstract}
Bioremediation is an important technology to remediate the chromium $(\mathrm{Cr})$ contaminated soil and water. In this study, Shewanella putrefaciens (MTTC8410) was used to investigate the influence of carbon concentration, $\mathrm{pH}$, and temperature on reduction of hexavalent chromium $[\mathrm{Cr}(\mathrm{VI})]$ into trivalent chromium [ $\mathrm{Cr}(\mathrm{III})]$. The increased bacterial growth rate was significantly reduced the $\mathrm{Cr}(\mathrm{VI})$ concentration. In batch mode experiments, $1 \%$ starch recorded the highest reduction of $\mathrm{Cr}(\mathrm{VI})(90 \%)$ followed by $1 \%$ glucose ( $88 \%$ reduction) and a reduction of $77 \%$ was by $1 \%$ cellulose. By using various pH conditions the maximum $\mathrm{Cr}(\mathrm{VI})$ reduction was achieved at $\mathrm{pH}$ 7.0. In this experiment the maximum $\mathrm{Cr}(\mathrm{VI})$ reduction $(75 \%)$ was observed at $35^{\circ} \mathrm{C}$, followed by $30^{\circ} \mathrm{C}$ with $62 \%$ of $\mathrm{Cr}(\mathrm{VI})$ reduction. Bioreactor analysis revealed the highest reduction of $\mathrm{Cr}(\mathrm{VI})(88 \%)$ in unsterile tannery effluent. The significant levels of physico- chemical parameters were reduced in unsterile tannery effluent, as compared to the sterile tannery effluent. The experimental results revealed that the $S$. putrefaciens (MTTC8410) could be used as a potential bacterial strain for reduction of $\mathrm{Cr}(\mathrm{VI})$ from contaminated groundwater.

Keywords: Shewanella putrefaciens, Bioremediation, $\mathrm{Cr}(\mathrm{VI})$ reduction, Tannary effluent, Black gram, Phytotoxicity assay
\end{abstract}

*Correspondence: pmayyasamy@gmail.com; +91-9486327103

(Received: April 15, 2020; accepted: November 16, 2020)

Citation: Thesai AS, Sangeetha R, Ashokkumar L, Palanivelan R, Rajakumar S, Ayyasamy PM. Evaluation of Cr(VI) Reducing Capability of Shewanella putrefaciens (MTTC8410) and Optimization of Operational Parameters. J Pure Appl Microbiol. 2020;14(4):2715-2727. doi: 10.22207/JPAM.14.4.49

(c) The Author(s) 2020. Open Access. This article is distributed under the terms of the Creative Commons Attribution 4.0 International License which permits unrestricted use, sharing, distribution, and reproduction in any medium, provided you give appropriate credit to the original author(s) and the source, provide a link to the Creative Commons license, and indicate if changes were made. 


\section{INTRODUCTION}

Chromium $(\mathrm{Cr})$ is the seventh most abundant element on earth, the twenty-first metal in the earth's crust and is mined as chromites ${ }^{1,2}$. The tannery industry is among the most contaminating industrial sectors and in the process of leather manufacture each tannery industry uses vast amounts of chemicals. The leather industries which widely use compounds containing $\mathrm{Cr}$ (III) in the tanning process generally release $\mathrm{Cr}(\mathrm{VI})$ effluents into natural water supplies, often without adequate effluent treatment, leading to anthropogenic contamination in water sources ${ }^{3}$. Chromium is one of the main contaminants in various engineering processes including tannery, electroplating, mining, fibre, metal processing, fertilizer, coloring and manufacturing of pigments ${ }^{4}$. Globally, $\mathrm{Cr}$ contamination estimates that the sector is accountable for the annual disposal into water of 300-400 million tons of heavy metals, solvents, toxic sludge and other wastes ${ }^{5}$. Among tannery effluent pollutants, $\mathrm{Cr}(\mathrm{VI})$ is one of the most toxic and causes various human health problems symptoms including nasal and skin irritation and lung carcinoma. While $\mathrm{Cr}(\mathrm{III})$ is harmless and insoluble, this is vital for human $\operatorname{diet}^{6,7}$. $\mathrm{Cr}$ can be found in various oxidation forms; $\mathrm{Cr}(\mathrm{VI})$ is the most toxic and soluble and $\mathrm{Cr}$ (III) is the least toxic form to human beings.

The traditional $\mathrm{Cr}$ management method included physical techniques (reverse osmosis, soil washing, membrane separation, exchange of ions, and adsorption) to remove $\mathrm{Cr}$ from the environment. Similarly, various chemical methods have also been used to extract $\mathrm{Cr}$ from aqueous media, including graphene-coated iron oxide (GCIO) nanoparticles ${ }^{8}$, maghemite nanoparticles ${ }^{9}$, iron oxide/carbon ${ }^{10}$ and mackinawite (FeS)coated sand ${ }^{11}$. Such strategies pose further drawbacks such as high costs, energy and secondary hazardous waste generation ${ }^{12-15}$. Biological removal of $\mathrm{Cr}$ is too good a process and option for the physical and chemical methods, as it is environmentally safe, less costly and lacks secondary emissions. Microbial bioremediation is a cost-effective and beneficial biosource for removing $\mathrm{Cr}$ from tannery and other industrial waste along with other harmful pollutants ${ }^{16,17}$. There are many microorganisms that play a crucial role in water, soil and air. A number of researchers previously successfully isolated a variety of possible microorganisms, minimizing effectiveness with $\mathrm{Cr}(\mathrm{VI})$. Some bacterial and fungal species such as Escherichia coli, Shewanella oneidensis, Bacillus firmus, Aspergillus niger and Pleurotus ostreatus were used to transform the $\mathrm{Cr}(\mathrm{VI})$ into $\mathrm{Cr}(\mathrm{III})^{18-22}$. The novelty of this study is to evaluate the ability of live cells of a bacterium namely S.putrefaciens (MTTC8410) to reduce the $\mathrm{Cr}(\mathrm{VI})$ into $\mathrm{Cr}(\mathrm{III})$. The batch process and bioreactor study was carried out for $\mathrm{Cr}$ reduction from chromium contaminated ground water.

The present study was aimed at evaluating S. putrefaciens' $\mathrm{Cr}(\mathrm{VI})$ reduction capability. Studies of the batch mode were performed by living bacterial cells. Under optimized conditions, the bacterial strain on $\mathrm{Cr}$ contaminated tannery effluent is checked via bioreactor analysis. The toxicity of treated wastewater samples from the bioreactor was examined using seed germination of on black gram.

\section{MATERIALS AND METHODS \\ Bacterial strain}

The S. putrefaciens (MTTC8410) utilized in this study was obtained from MTCC Chandigarh in India. It was sub cultured in the laboratory using Luria broth medium. The bacterial strain was maintained by nutrient agar slant. The bacterial strain was subcultured every month and preserved using a glycerol solution $20 \%$ and stored at $4^{\circ} \mathrm{C}$ for further studies.

\section{Media and chemicals}

The optimization of potential bacterial strain was performed by using mineral salt medium. All analytical grade chemicals and reagents were purchased from Loba Chemie Laboratories (Mumbai, India) and Hi-media Laboratories (Mumbai, India).

\section{Influence of $\mathrm{Cr}(\mathrm{VI})$ on bacterial growth}

An influence of different concentrations of $\operatorname{Cr}(\mathrm{VI})$ on the bacteria's growth rate was investigated. Shewanella putrefaciens strain (MTTC8410) was grown at $120 \mathrm{rpm}$ and $\mathrm{pH} 7.0$ in a rotary shaker (model: OrbiTech LETT, India), whereas the temperature in LB broth medium was $37^{\circ} \mathrm{C}$ supplemented by $\mathrm{Cr}(\mathrm{VI})$ range 10 to 30 $\mathrm{mg} / \mathrm{L}^{23}$. Every $4 \mathrm{hrs}$ time interval $5 \mathrm{ml}$ samples were obtained from the conical flasks. Followed by the samples were collected and centrifuged 
for $10 \mathrm{~min}$ at $3000 \mathrm{rpm}$. The pellet was then dissolved with sterile distilled water and calculated growth rate was measured at $600 \mathrm{~nm}$ using UVspectrophotometer (model: Cyber lab-UV-100, USA) ${ }^{24}$.

Biochemical tests of S.putrefaciens (MTTC8410)

The S.putrefaciens (MTTC8410) was qualitatively investigated for its ability to produce various enzymes viz, amylase ${ }^{25}$, cellulose ${ }^{26}$, chitinase $^{27}$, gelatinase ${ }^{28}$, tryptophanase ${ }^{29}$, citrase, L-asparginase ${ }^{30}$, protease $^{31}$, tannase ${ }^{32}$, oxidase and catalase by appropriate standard method.

Effect of carbon sources on reduction of $\mathrm{Cr}(\mathrm{VI})$

Shewanella putrefaciens (MTTC-8410)

was used to evaluate the influence of various carbons sources on the reduction of $\mathrm{Cr}(\mathrm{VI})$. So far, $100 \mathrm{ml}$ mineral salt medium (MSM) was prepared in $250 \mathrm{ml}$ conical flasks with various concentrations of carbon sources $(0.5,1$ and 1.5 per cent) and amended with $10 \mathrm{mg} \mathrm{Cr}(\mathrm{VI})$ and all flasks were sterilized. After the sterilization individually, $1 \%$ of S. putrefaciens (MTTC-8410) was transferred by aseptically ${ }^{33}$. Flasks were then kept for 10 days in shaker at $37^{\circ} \mathrm{C}$ at125 rpm. Then $5 \mathrm{ml}$ of sample were taken from all conical flasks at every 24 hrs time interval. After this the collected samples were spun at $3000 \mathrm{rpm}$ for 10 $\mathrm{min}$. Then aqueous phase was withdrawn from the centrifuge tube and chromium was estimated by DPC (diphenylcarbazide) method using in UVspectrophotometer at $540 \mathrm{~nm}$ (model: Cyber lab-UV-100, USA). The culture growth rate was measured simultaneously, at $600 \mathrm{~nm}$.

Effect of different $\mathrm{pH}$ conditions on $\mathrm{Cr}(\mathrm{VI})$ reduction

S. putrefaciens was used to assess the effectiveness of different $\mathrm{pH}$ conditions on the $\mathrm{Cr}(\mathrm{VI})$ reduction. In which various $\mathrm{pH}$ of (5 to 9) $100 \mathrm{ml}$ (MSM) medium were prepared with optimized carbon source 0.5 per cent starch in $250 \mathrm{ml}$ conical flasks and adjusted with $10 \mathrm{mg}$ $\mathrm{Cr}(\mathrm{VI})$ and all flasks were sterilized. After the sterilization $1 \%$ of S. putrefaciens (MTTC-8410) was transferred to individual conical flask by aseptically ${ }^{34}$. Flasks were then kept for 10 days in shaker at $37^{\circ} \mathrm{C}$ with $125 \mathrm{rpm}$. Then $5 \mathrm{ml}$ of sample were taken from all conical flasks at every $24 \mathrm{hrs}$ time interval. After this the collected samples were spun at $3000 \mathrm{rpm}$ for $10 \mathrm{~min}$. Then aqueous phase was withdrawn from the centrifuge tube and $\mathrm{Cr}(\mathrm{VI})$ was estimated by DPC method in UVspectrophotometer at $540 \mathrm{~nm}$ (model: Cyber labUV-100, USA). Simultaneously the culture growth rate was measured at $600 \mathrm{~nm}$.

Influence of temperature on $\mathrm{Cr}(\mathrm{VI})$ reduction

Shewanella putrefaciens (MTTC-8410) was used to assess the influence of different temperatures on reduction of $\mathrm{Cr}(\mathrm{VI})$. Hence, in $250 \mathrm{ml}$ conical flasks $100 \mathrm{ml}$ (MSM) medium was prepared with optimized carbon source $0.5 \%$ starch and amended with $10 \mathrm{mg} \mathrm{Cr}(\mathrm{VI})$ and all flasks were sterilized. After the sterilization $1 \%$ of $S$. putrefaciens was transferred to individual conical flask by aseptically. Then conical flasks were kept in shaker under different temperatures $\left(25\right.$ to $45^{\circ} \mathrm{C}$ ) at $125 \mathrm{rpm}$ for 10 days $^{35}$. Followed by $5 \mathrm{ml}$ of sample was taken from all conical flasks at every $24 \mathrm{hrs}$ time interval. After this the collected samples were spun at $3000 \mathrm{rpm}$ for $10 \mathrm{~min}$. Then aqueous phase was withdrawn from the centrifuge tube and $\mathrm{Cr}(\mathrm{VI})$ was estimated by DPC method in UV-spectrophotometer at $540 \mathrm{~nm}$ (model: Cyber lab-UV-100, USA). Simultaneously the culture growth rate was measured at $600 \mathrm{~nm}$.

\section{Analytical method}

The $[\mathrm{Cr}(\mathrm{VI})]$ was determined using the (DPC) procedure using a UV-spectrophotometer (model: cyber lab-UV-100, USA) ${ }^{36}$. Around $0.025 \mathrm{~g}$ of DPC was mixed with $9.67 \mathrm{ml}$ of acetone and 330 $\mathrm{ml}$ of $3 \mathrm{M} \mathrm{H}_{2} \mathrm{SO}_{4}$. The absorbance was calculated at $540 \mathrm{~nm}$ and all assays were performed in triplicates, and mean values were recorded.

\section{Bioreduction of chromium from tannery effluent} using lab scale bioreactors

The tannery effluent treatment method was planned and the setup was made as shown in (Fig. 1). This set up was prepared based on the pilot scale water treatment plant ${ }^{37}$. The tannery effluent was obtained from tannery industry in Periyakulam, district of Erode, Tamil Nadu. The sample was collected in sterile container and was taken to the laboratory and analyzed for various physicochemical parameters ${ }^{38}$. The established lab scale bioreactors have a capacity of 10 liters and are made of tarson. Mechanical stirrers were installed in the reactor tank and the settling tanks. Artificial aerator was connected to both bioreactors for aeration purpose. About 10 liters of tannery effluent containing $20 \mathrm{mg}$ of $\mathrm{Cr}(\mathrm{VI})$ was subjected to primary (bioprocess) treatment 
and inoculated with S.putrefaciens. Then $5 \mathrm{ml}$ of sample was taken from all conical flasks at every 24 hrs time interval. After this the collected samples were spun at $3000 \mathrm{rpm}$ for $10 \mathrm{~min}$. Then aqueous phase was withdrawn from the centrifuge tube and $\mathrm{Cr}(\mathrm{VI})$ was estimated by DPC method using UV-spectrophotometer at $540 \mathrm{~nm}$ (model: Cyber lab-UV-100, USA). Simultaneously the culture growth rate was measured at $600 \mathrm{~nm}$. Further, all physic-chemical parameters were analyzed before and after the treatment of tannery effluent.

\section{Reactor 1 (R1)}

$+1 \%$ inoculum

Unsterile tannery effluent $+0.5 \%$ starch

\section{Reactor 2 (R2)}

Sterile tannery effluent $+0.5 \%$ starch + $1 \%$ inoculum

\section{Phytotoxicity assay}

Pot culture experiments were performed to evaluate the toxicity of the treated and untreated tannery effluent. The fertile soil was collected without any contamination near Omalur Taluk of Salem district. The $\mathrm{Cr}(\mathrm{VI})$ amended soil was filled in sterile plastic cups with the dimensions of $5 \times 15 \mathrm{~cm}$. The black gram seeds obtained from the licensed agency and surface sterilized by mercury chloride $\left(\mathrm{HgCl}_{2}\right)(0.1 \%, \mathrm{w} / \mathrm{v})$. Four seeds were

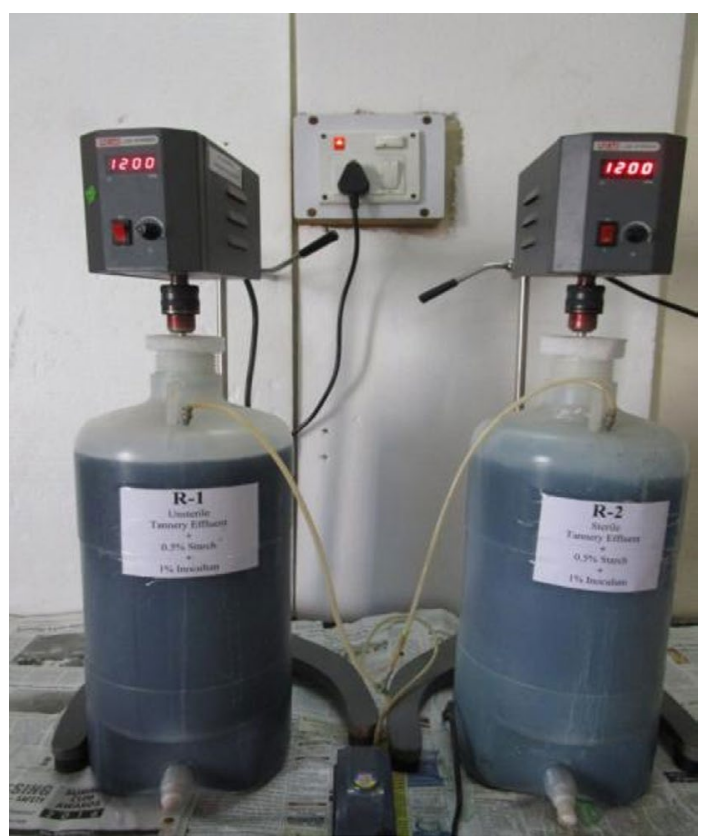

Fig. 1. Bioreduction of chromium contaminated tannery effluent through lab scale bioreactor study sowed in each cup and the set up was kept for phytotoxicity assay. In each pot containing black gram (Vigna mungo) the treated and untreated tannery effluents at varying percentages viz 25, 50,75 and $100 \%$ were irrigated and allowed to germinate the plants. Control pot was irrigated with tap water to compare the efficiency of the treatment. Germination of the seeds was noted after $3^{\text {rd }}$ day of irrigation and calculated ${ }^{39}$.

\section{Statistical Analysis}

All tests were performed in triplicates and reduction of $\mathrm{Cr}(\mathrm{VI})$ was evaluated using error bars $^{40}$. Data were statistically analyzed using the Microsoft ${ }^{\circledR}$ Excel (Version 2010) statistical package.

\section{RESULTS AND DISCUSSION Effect of $\mathrm{Cr}(\mathrm{VI})$ on bacterial growth rate}

The influence of different $\mathrm{Cr}(\mathrm{VI})$ (10 and $30 \mathrm{mg} / \mathrm{L}$ ) concentrations on the growth of S.putrefaciens has been performed and presented in (Fig.2). The interaction between cell growth and varying $\mathrm{Cr}(\mathrm{VI})$ concentration was studied at $24 \mathrm{hrs}$ time of incubation. The rate of bacterial growth in LB media without $\mathrm{Cr}(\mathrm{VI})$ was very significant as compared to the LB medium containing $\mathrm{Cr}(\mathrm{VI})$ 10 and $30 \mathrm{mg} / \mathrm{L}$ containing. In which $10 \mathrm{mg} / \mathrm{L}$ of $\mathrm{Cr}(\mathrm{VI})$ has a minor effect on the development of bacterial cells. $\mathrm{Cr}(\mathrm{VI})$ at a concentration of 10 to $30 \mathrm{mg} / \mathrm{L}$ have negatively effect on the growth of the bacteria. The previous study reported that concentration of $\mathrm{Cr}(\mathrm{VI})$ in the range of 10 and $20 \mathrm{mg} / \mathrm{L}$ would have a small impact on Bacillus sp. growth, while $100 \mathrm{mg} / \mathrm{L}$ of $\mathrm{Cr}(\mathrm{VI})$ was greatly inhibit the bacterial growth ${ }^{41}$. The present study

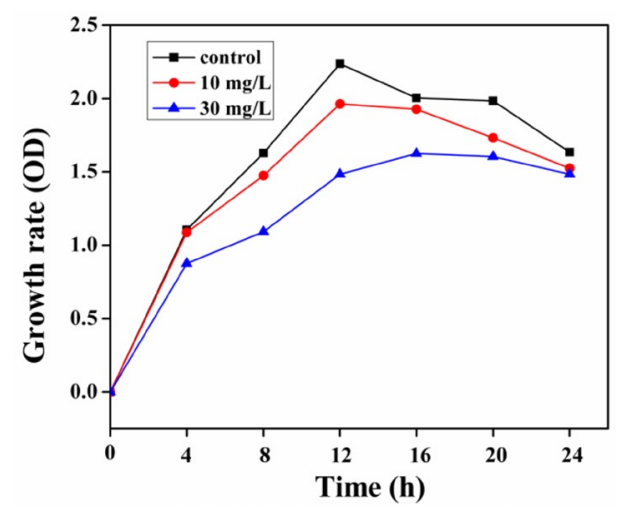

Fig. 2. Influence of $\mathrm{Cr}(\mathrm{VI})$ on bacterial growth rate 
reported a decrease in Escherichia coli ATCC 33456 growth rate during lag phase due to the increased concentrations of $\mathrm{Cr}(\mathrm{VI})^{42}$.

\section{Biochemical tests of $S$. putrefaciens}

The enzymatic characteristic of $\mathrm{S}$ putrefaciens was presented in Fig. 3. The strain developed a clear zone around the culture in starch agar medium, but in the case of cellulose, chitinase and pectinase enzyme assay, the culture could not develop the clear zone around the colonies due to the lack of enzyme producing gene. The $S$. putrefaciens (MTTC-8410) can produce enzymes like gelatinase, tryptophanase, citrase, L- Asparginase, protease, oxidase and catalase and it was confirmed by the strain developed a clear zone in respective media. Similar results were reported by $\mathrm{Cr}$ reducing Pseudomonas species ${ }^{43}$.

\section{Effect of different concentrations of glucose on $\mathrm{Cr}(\mathrm{VI})$ reduction}

The effect of different doses of glucose (0.5, 1 and 1.5 percent) on reduction of $\mathrm{Cr}(\mathrm{VI})$ by $S$. putrefaciens was presented in Fig. 4a. In which, by using $0.5 \%$ of glucose, no significant $\mathrm{Cr}(\mathrm{VI})$ reduction was observed from $1^{\text {st }}$ to $5^{\text {th }}$ day of experiment. After the $5^{\text {th }}$ day of experiment, slight significant $\mathrm{Cr}(\mathrm{VI})$ reduction (82\%) was observed. By using $1 \%$ of glucose, the maximum $\mathrm{Cr}(\mathrm{VI})$ reduction $(88 \%)$ was observed in $8^{\text {th }}$ day to $10^{\text {th }}$ of day of experiment. The previous study reported that glucose was donor of electrons, which could easily be oxidized glucose ${ }^{44}$. Some previous research reported that glucose can play a good carbon source while act as a efficient electron donor to reduce $\mathrm{Cr}(\mathrm{VI})$ by bacteria ${ }^{45-47}$. By
(A) Amylase

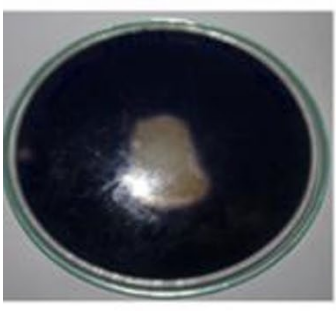

(D) Gelatinase

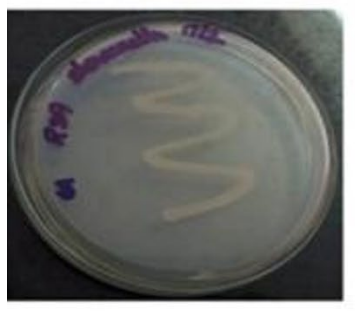

(E)Tryptophanase
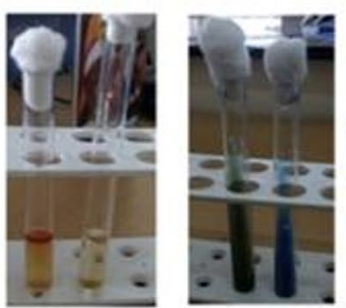

(I) Tannase

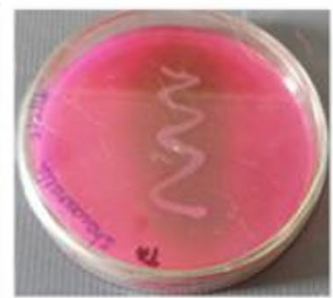

(C) Chitinase

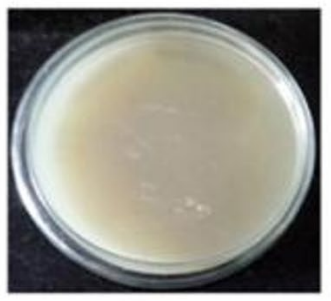

(G) L-Asparginase

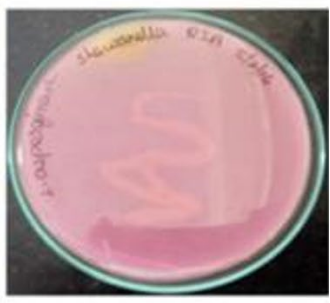

(J) Oxidase and Catalase

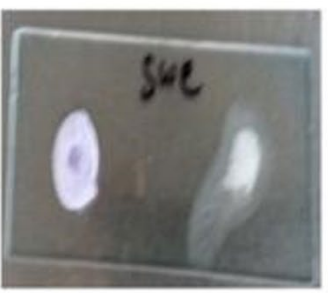

Fig.3. Biochemical tests of Shewanella putrefaciens (MTTC8410) 
using $1.5 \%$ of glucose, $80 \%$ of $\mathrm{Cr}(\mathrm{VI})$ reduction was observed. Overall in this different concentration of glucose optimization, $1 \%$ of glucose achieved very significant $\mathrm{Cr}(\mathrm{VI})$ reduction. Previously many researchers reported that glucose is a known electron donor to several bacterial strains for $\mathrm{Cr}(\mathrm{VI})$ reduction ${ }^{48}$. Fig. $4 b$ showed the growth rate of $S$. putrefaciens by various doses of glucose in MSM medium containing $10 \mathrm{mg}$ of $\mathrm{Cr}(\mathrm{VI})$. In this study by using $0.5 \%$ of glucose, there was no significant growth observed from $1^{\text {st }}$ day to $10^{\text {th }}$ day of experiment and it does not influence the $\mathrm{Cr}(\mathrm{VI})$ reduction. But by using 1 and $1.5 \%$ of glucose the significant $\mathrm{Cr}(\mathrm{VI})$ reduction was observed. In which both 1 and $1.5 \%$ of glucose can influence the $\mathrm{Cr}(\mathrm{VI})$ reduction as well as growth rate of $S$. putrefaciens. Different concentrations of cellulose on $\mathrm{Cr}(\mathrm{VI})$ reduction.

The effect of different doses of cellulose $(0.5,1$ and 1.5 percent) on reduction of $\mathrm{Cr}(\mathrm{VI})$ by
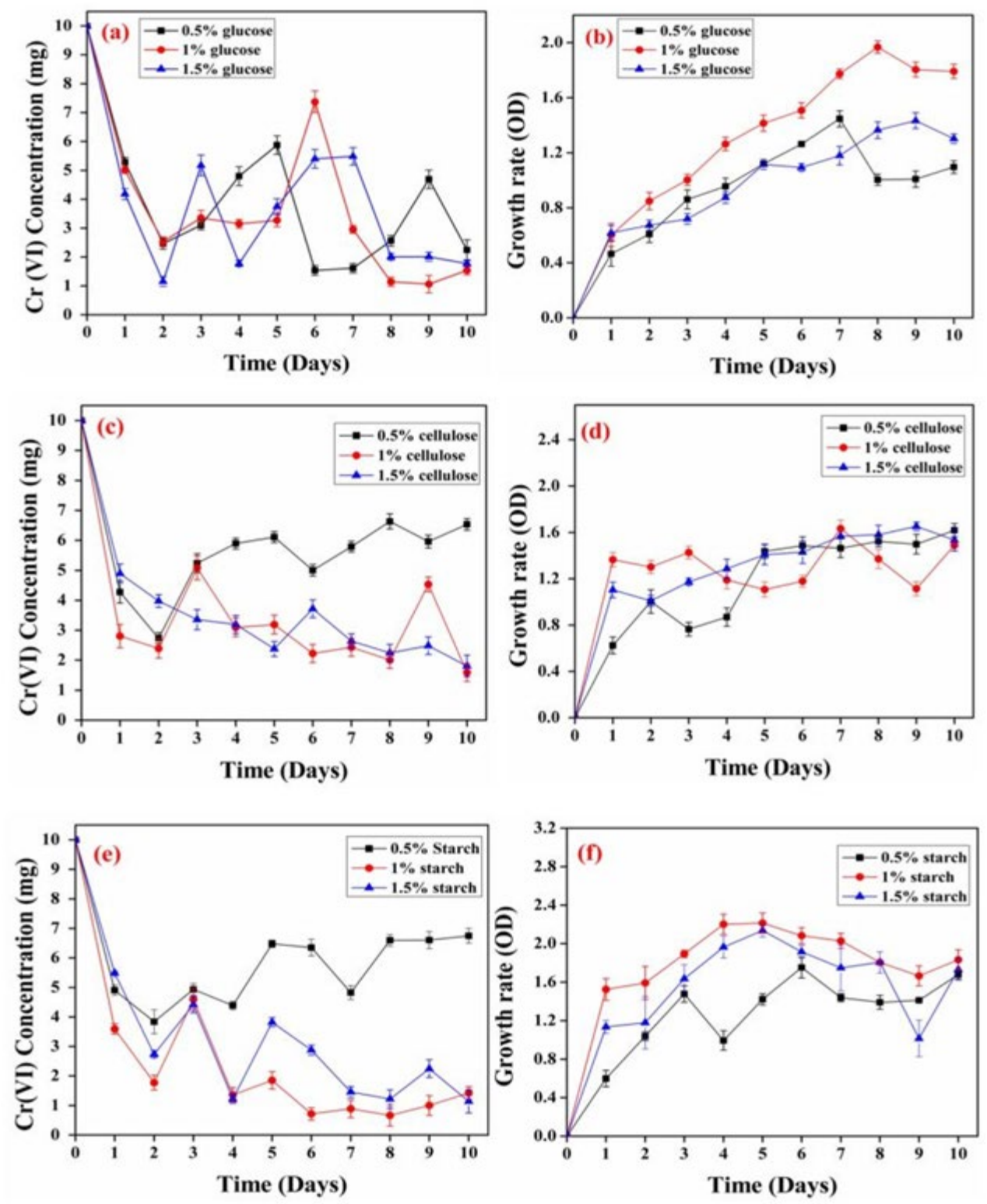

Fig. 4. Influence of various carbon sources on the reduction of hexavalent chromium 
S. putrefaciens was presented in (Fig.4c). In this experiment, by using $0.5 \%$ of cellulose, there was very poor $\mathrm{Cr}(\mathrm{VI})$ reduction was observed. By using $1 \%$ of cellulose, $77 \%$ of $\mathrm{Cr}(\mathrm{VI})$ reduction was observed in $6^{\text {th }}$ to $8^{\text {th }}$ day of experiment. Followed by using $1.5 \%$ of cellulose, there was $75 \%$ of $\mathrm{Cr}(\mathrm{VI})$ reduction from $5^{\text {th }}$ to $10^{\text {th }}$ day of experiment. Fig. $4 \mathrm{~d}$ showed the growth rate of $S$. putrefaciens under various concentrations of cellulose $(0.5$, 1 and 1.5\%) in MSM medium containing $10 \mathrm{mg}$ of $\mathrm{Cr}(\mathrm{VI})$. In this study by using $0.5 \%$ of glucose, better significant growth was observed from $1^{\text {st }}$ day to $10^{\text {th }}$ day of experiment and it also contribute poor influence on $\mathrm{Cr}(\mathrm{VI})$ reduction. But by using 1 and $1.5 \%$ of cellulose, significant chromium reduction was observed. In which both 1 and $1.5 \%$ of glucose can influence the $\mathrm{Cr}(\mathrm{VI})$ reduction as well as growth rate of $S$. putrefaciens. Previous study reported that a number of electron donors play an important role for the reduction of $\mathrm{Cr}(\mathrm{VI})$ by Ganoderm lucidum ${ }^{49}$.

\section{Effect of different concentrations of starch on $\mathrm{Cr}(\mathrm{VI})$ reduction}

The effect of different doses of starch $(0.5,1$ and 1.5 percent) on reduction of $\mathrm{Cr}(\mathrm{VI})$ by S. putrefaciens was presented in (Fig.4e). In this study, by using $0.5 \%$ starch, there was considerable $\mathrm{Cr}(\mathrm{VI})$ reduction was observed in first two days, after that on the $3^{\text {rd }}$ day of experiment it loss the $\mathrm{Cr}(\mathrm{VI})$ capacity. Using $1 \%$ of starch, $90 \%$ of $\mathrm{Cr}(\mathrm{VI})$ reduction was observed in $6^{\text {th }}$ to $9^{\text {th }}$ day of experiment. Followed by using $1.5 \%$ of starch, there was $79 \%$ of $\mathrm{Cr}(\mathrm{VI})$ reduction was achieved from $7^{\text {th }}$ to $8^{\text {th }}$ day of experiment. The electron donors of carbon sources influenced the $\mathrm{Cr}(\mathrm{VI})$ reduction by using Brevibacterium casei ${ }^{50}$. Fig. $4 \mathrm{f}$ was showed the growth rate of S.putrefaciens under various concentrations of starch $(0.5,1$ and $1.5 \%$ ) in MSM medium containing $10 \mathrm{mg}$ of hexavalent chromium. In this study, by using $1 \%$ of starch was can influenced the maximum level of $\mathrm{Cr}(\mathrm{VI})$ reduction and growth rate of S.putrefaciens when compared to 0.5 and $1.5 \%$ of starch.
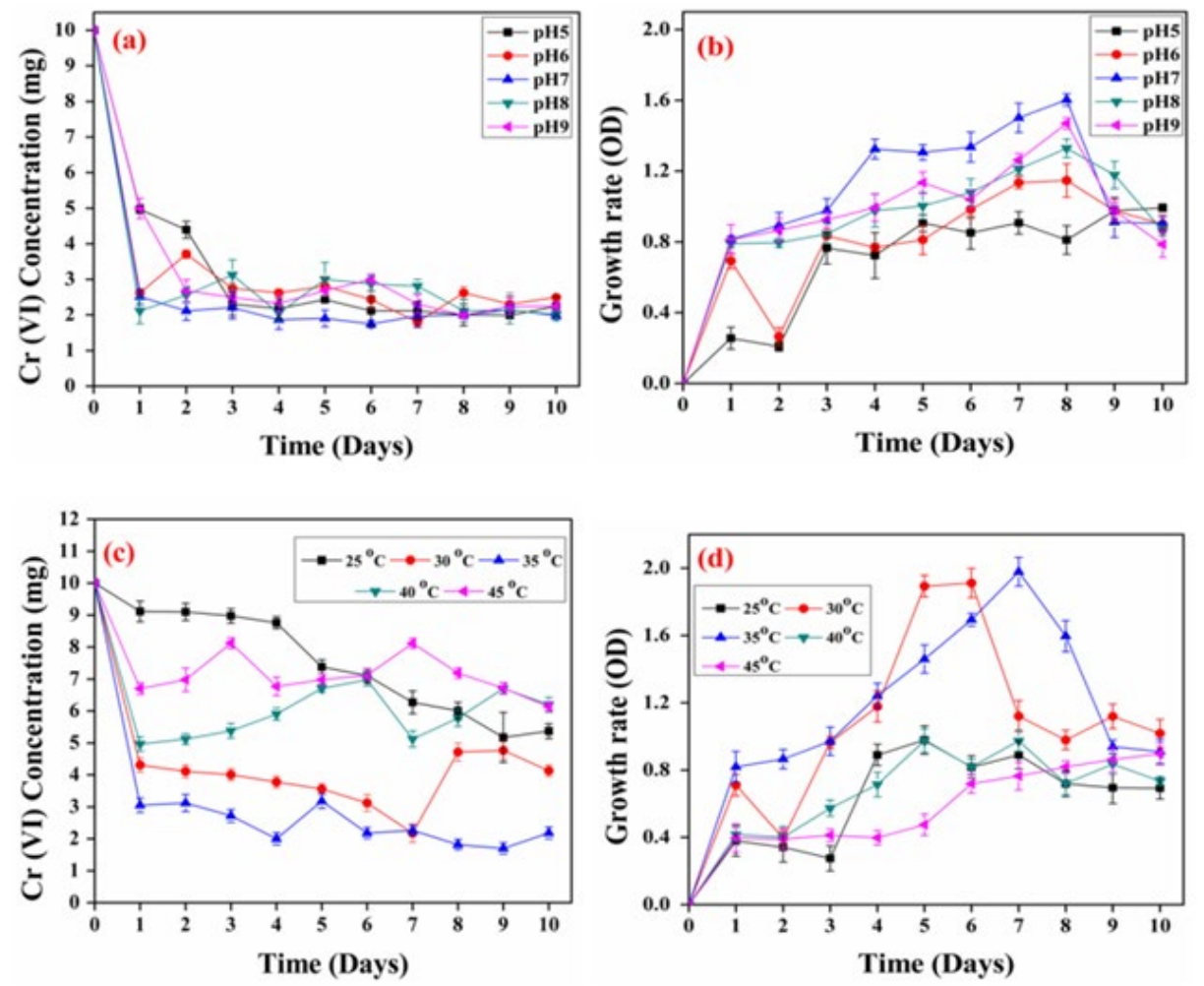

Fig. 5. Influence of various $\mathrm{pH}$ and temperatures on reduction of hexavalent chromium 
Influence of different concentrations of $\mathrm{pH}$ $(5,6,7,8$ and 9$)$

The reduction of $\mathrm{Cr}(\mathrm{VI})$ under various $\mathrm{pH}$ conditions by using S.putrefaciens was shown in Figure 5a. The $\mathrm{pH}$ has an influence on $\mathrm{Cr}(\mathrm{VI})$ bioreduction. The effects of incubation period on reduction of $\mathrm{Cr}(\mathrm{VI})$ at various $\mathrm{pH}(5,6,7,8$ and 9) was analyzed (The operation conditions; $10 \mathrm{mg}$ of $\mathrm{Cr}(\mathrm{VI}) / 100 \mathrm{ml}$ medium, temperature $37^{\circ} \mathrm{C}$ and $1 \mathrm{ml}$ of one OD inoculums). In this study, all $\mathrm{pH}$ from
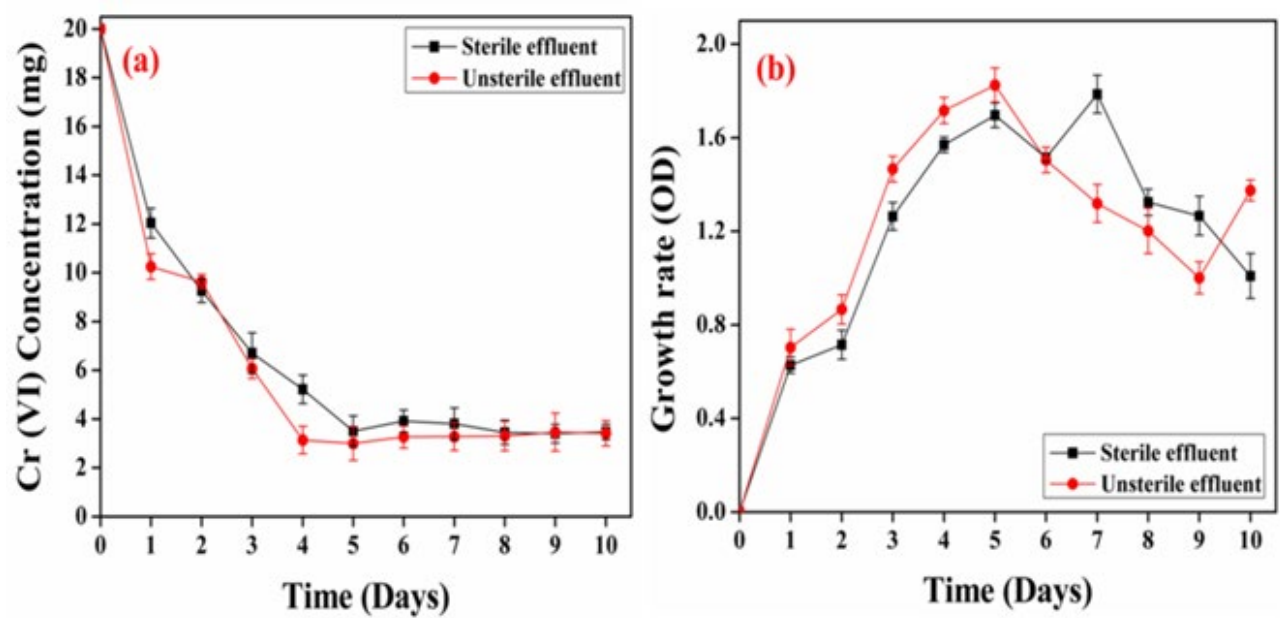

Fig. 6. Bioreduction of chromium contaminated tannery effluent through lab scale bioreactor

Table 1. Physico-chemical parameters of untreated tannery effluent, treated sterile tannery effluent and treated unsterile tannery effluent

\begin{tabular}{|c|c|c|c|c|}
\hline S.No & Parameters & $\begin{array}{l}\text { Untreated tannery } \\
\text { effluent }\end{array}$ & $\begin{array}{l}\text { Treated sterile } \\
\text { tannery effluent }\end{array}$ & $\begin{array}{l}\text { Treated unsterile } \\
\text { tannery effluent }\end{array}$ \\
\hline 1 & Colour & Dark Black & Light Black & Black \\
\hline 2 & $\mathrm{pH}$ & 7.86 & 7.54 & 7.24 \\
\hline 3 & Turbitidy & Above 200 & Above 400 & Above 400 \\
\hline 4 & $\begin{array}{l}\text { Electrical/Specific } \\
\text { conductivity }\end{array}$ & $\begin{array}{l}7890 \text { Micro } \\
\mathrm{mho} / \mathrm{cm}\end{array}$ & $\begin{array}{l}4368 \mathrm{Micro} \\
\mathrm{mho} / \mathrm{cm}\end{array}$ & $\begin{array}{l}4308 \text { Micro } \\
\mathrm{mho} / \mathrm{cm}\end{array}$ \\
\hline 5 & Total dissolved solid & 4385 & 2401 & 2101 \\
\hline 6 & Total suspended solid & 660 & 330 & 290 \\
\hline 7 & Total Hardness & 2842 & 1042 & 981 \\
\hline 8 & Chromium & 20 & 5 & 2.3 \\
\hline 9 & Chloride & 1124 & 1216 & 1016 \\
\hline 10 & Sulphate & 390 & 234 & 211 \\
\hline 11 & Calcium & 656 & 136 & 98 \\
\hline 12 & Magnesium & 220 & 170 & 112 \\
\hline 13 & Sodium & 118 & 98 & 83 \\
\hline 14 & Pottassium & 98 & 73 & 71 \\
\hline 15 & $\begin{array}{l}\text { Biological oxygen } \\
\text { demand }\end{array}$ & 223 & 78 & 74 \\
\hline 16 & $\begin{array}{l}\text { Chemical oxygen } \\
\text { demand }\end{array}$ & 458 & 94 & 88 \\
\hline 17 & Nitrate & 6.4 & 6.4 & 5.3 \\
\hline 18 & Phosphate & 1.0 & 1.0 & 1.0 \\
\hline 19 & Manganese & 1.6 & 1.6 & 1.6 \\
\hline 20 & Phenolic compound & 2.1 & 2.1 & 2.1 \\
\hline 21 & Fluorides & 1.8 & 1.8 & 1.8 \\
\hline
\end{tabular}

Journal of Pure and Applied Microbiology 
5 to 9 was very significantly reduced the $\mathrm{Cr}(\mathrm{VI})$ from the aqueous solution. In this experiment the maximum $\mathrm{Cr}(\mathrm{VI})$ reduction was observed at $\mathrm{pH} 7$. The similar result was observed that the maximum removal of $\mathrm{Cr}(\mathrm{VI})(88 \%)$ by $\mathrm{PCP} 3$ strain at $\mathrm{pH} 7.0^{51}$. So the further studies were carried out at $\mathrm{pH} 7$. The reduction of $\mathrm{Cr}(\mathrm{VI})$ during low $\mathrm{pH}$ may be due to the relationship of bioaccumulation and functional group dissociation $^{52}$. The (Fig. 5b) was showed the growth rate of $S$. putrefaciens under various $\mathrm{pH}$ conditions. All pH levels significantly influenced the growth rate.

Influence of different temperature of $\mathrm{pH}(25,30$, 35,40 and $45^{\circ} \mathrm{C}$ )

Temperature is one of the important key for microbial growth $\mathrm{Cr}(\mathrm{VI})$ reduction. The effectiveness of various temperatures on reduction of $\mathrm{Cr}(\mathrm{VI})$ by S. putrefaciens were presented in (Fig. $5 \mathrm{c})$. In this study, the maximum $\mathrm{Cr}(\mathrm{VI})$ reduction (75\%) was observed at $35^{\circ} \mathrm{C}$. Followed by $30^{\circ} \mathrm{C}$ was showed the $62 \%$ of $\mathrm{Cr}(\mathrm{VI})$ reduction. The previous study was reported that hat $30^{\circ} \mathrm{C}$ was significantly encourage the growth of Bacillus $\mathrm{KCH} 3$ and growth was inhibited by below $15^{\circ} \mathrm{C}$ and above $40^{\circ} \mathrm{C}^{53}$. The significant bacterial growth achieved by $30^{\circ} \mathrm{C}$ and $35^{\circ} \mathrm{C}$ when compared to other temperatures (Fig. 5d). The similar result was observed that the maximum removal of $\mathrm{Cr}(\mathrm{VI})(85.87 \%)$ by Brevibacillus sp at $35^{\circ} \mathrm{C}^{54}$.

Bioreduction of chromium contaminated tannery effluent through lab scale bioreactor

Bioreduction of chromium contaminated tannery effluent through lab scale bioreactor results were presented in (Fig. 6a). In sterile effluent, the maximum $\mathrm{Cr}(\mathrm{VI})$ reduction (84\%) was observed from $4^{\text {th }}$ day to throughout the study. In unsterile effluent, the maximum $\mathrm{Cr}(\mathrm{VI})$ reduction (88\%) was observed from $5^{\text {th }}$ day to throughout the study. The significant $\mathrm{Cr}(\mathrm{VI})$ reduction was obtained in bioreactor study, due to more biochemical reactions to convert raw materials to products through the action of biocatalyst and enzyme of microorganisms. The growth rate of S.putrefaciens was presented in (Fig. 6b). In unsterile effluent, growth rate was very significantly high because of unsterile effluent have native microbes, hence those native microbes also influence the $\mathrm{Cr}(\mathrm{VI})$ reduction and growth rate.

Physicochemical parameters of untreated and treated tannery effluent

The physicochemical parameters of the raw tannery effluent, treated sterile tannery effluent and treated unsterile tannery effluent were described in Table 1 . The tannery effluent

Table 2. Effectiveness of various concentrations of treated and untreated tannery effluent on germination and seedling growth of black gram (Vigna mungo)

\begin{tabular}{lcccccccc}
\hline Reactors & Effluent con. & \multicolumn{7}{c}{ Shoot length (cm)/days } \\
\cline { 3 - 8 } & & 1 & 2 & 3 & 4 & 5 & 6 & 7 \\
\hline & $25 \%$ & + & + & + & 2.2 & 3.6 & 7.8 & 10.2 \\
Reactor 1 & $50 \%$ & + & + & + & 1.9 & 3.1 & 6.5 & 8.9 \\
Sterile effluent & $75 \%$ & - & + & + & 1.6 & 2.8 & 6.1 & 7.7 \\
0.5\% starch & $100 \%$ & - & + & + & 1.2 & 1.9 & 5.6 & 6.9 \\
& control & - & + & + & 3.4 & 4.1 & 8 & 10.8 \\
& $25 \%$ & + & + & + & 2.6 & 4.1 & 8 & 11 \\
Reactor 1 & $50 \%$ & - & + & + & 1.9 & 2.8 & 6.2 & 9.3 \\
Unsterile effluent & $75 \%$ & - & + & + & 1.3 & 2.1 & 5.6 & 8.4 \\
0.5\% starch & $100 \%$ & - & - & + & + & 1.6 & 3.2 & 7.4 \\
& control & + & + & + & 3.1 & 4.6 & 8.8 & 11.5 \\
Untreated raw & $25 \%$ & - & - & + & + & 0.8 & 1.3 & 2 \\
effluent & $50 \%$ & - & - & - & + & 0.5 & 0.9 & 1.2 \\
& $75 \%$ & - & - & - & - & $N$ & NG & NG \\
& $100 \%$ & - & - & - & - & NG & NG & NG \\
& control & + & + & + & 3.2 & 4.4 & 7.2 & 8.2 \\
\hline
\end{tabular}

+ (Germination) $\quad$ - (No Germination) 
contained high concentrations of salts and other parameters above the permissible limits. The high concentration of $\mathrm{Cr}$, organic material and salinity in the effluents released from tanneries are considered to be the major hazard ${ }^{55,56}$. The collected tannery effluent contains higher concentrations of BOD (Biochemical oxygen demand) and COD (Chemical oxygen demand) along with other parameters. The similar results were reported that, tannery effluent was having high BOD and COD concentrations ${ }^{57}$. After the treatment of sterile tannery effluent by using S.putrefaciens, most of the salts and other parameters were reduced up to permissible limits fixed by the BIS (Bureau of Indian Standards). In this study, because of the use of dissolved organic substances by bacterial strain $^{58}$, S. putrefaciens significantly decreased the BOD and COD of tannery effluent. Furthermore, after the treatment of unsterile tannery effluent by using S.putrefaciens, most of the salts and other parameters were reduced permissible limits fixed the BIS and other organizations. The physicchemical parameters of unsterile treated effluent were significantly reduced as compared to the treated sterile tannery effluent.

\section{Phytotoxicity assay by pot culture method}

The data regarding phytotoxicity assay of treated and untreated tannery effluent studies has been presented in (Table 2). In treated sterile tannery effluent (25 to $100 \%$ ), significant black gram seed germination was observed every day. In treated unsterile tannery effluent (25 to $100 \%)$, very significant growth was observed when compared to treated sterile effluent. The similar results were reported by using bacterial strain $\mathrm{pv}_{26}{ }^{59}$. But in the case of raw untreated tannery effluent very poor growth rate was observed by using 25 and $50 \%$ of raw untreated effluent and there was no growth observed when using 75 and $100 \%$ raw untreated tannery effluent. At higher concentrations (80 and 100\%) tannery effluent inhibited germination of black gram due to toxicity and stress by using untreated effluent ${ }^{60}$. The previous study reported that the higher tannery effluent concentration reduces the dehydrogenase activity of the enzyme, which may be changing to disrupt germination and seedling growth ${ }^{61}$. This study was revealed that after the treatment of tannery effluent by using S.putrefaciens the treated effluent was did not showed toxic effects on black gram plants.

\section{CONCLUSIONS}

Shewanella putrefaciens strain (MTTC8410) was investigated for its an ability to reduce $\mathrm{Cr}(\mathrm{VI})$ into $\mathrm{Cr}(\mathrm{III})$. In this study the maximum $\mathrm{Cr}(\mathrm{VI})$ reduction was achieved at $\mathrm{pH}$ 7.0 and temperature $37^{\circ} \mathrm{C}$. In the bioreactor test, S.putrefacien maximum $\mathrm{Cr}(\mathrm{VI})$ reduction capacity was $97 \%$. Consecutive experiment for the toxicity of treated tannery effluent on black gram showed no toxicity in plant growth parameters. The bacterially treated tannery effluent has very less amount of $\mathrm{Cr}$, due to this nature its harmless for the agricultural crops. Hence, it was recommended that the S.putrefaciens (MTTC8410) have potential to reduce $\mathrm{Cr}(\mathrm{VI})$ from aqueous media.

\section{ACKNOWLEDGMENTS}

We would like to express our heartfelt thanks to Vice Chancellor for providing lab facilities. Thanks to Microbial Type Culture Collection (MTCC) and Gene Bank, Chandigarh, India for providing bacterial strain.

\section{CONFLICT OF INTEREST}

The authors declare that there is no conflict of interest.

\section{AUTHORS' CONTRIBUTION}

All authors have made a substantial, direct, and intellectual contribution to the work and approve it for publication.

\section{FUNDING}

The research was financially supported by the University Grant Commission, New Delhi under the Basic Scientific Research scheme (Sanction No. F-25-1/2013-14(BSR)/11-142/10) and and the FIST grants of Department of Science and Technology (Ref No. SR/FST/LSI-640/2015(C) Dt. 30/5/2016).

\section{DATA AVAILABILITY}

All datasets generated or analyzed during this study are included in the manuscript.

\section{ETHICS STATEMENT}

This article does not contain any studies 
with human participants or animals performed by any of the authors.

\section{REFERENCES}

1. Cervantes C, Campos-Garcia J. Reduction and Efflux of chromate by Bacteria. Mol Microbiol Heavy Metals. 2007:407-419. doi: 10.1007/7171_2006_087

2. Bakshia A, Panigrahib AK. A comprehensive review on chromium induced alterations in fresh water fishes. Toxicol Reports. 2018;5:440-447. doi: 10.1016/j. toxrep.2018.03.007

3. Cheung $\mathrm{KH}, \mathrm{Gu}$ JD. Mechanism of hexavalent chromium detoxification by microorganisms and bioremediation application potential: a review. Int Biodeterior Biodegrad. 2007;59:8-15. doi: 10.1016/j. ibiod.2006.05.002

4. Sathvika T, Manasi M, Rajesh V, Rajesh N. Adsorption of chromium supported with various column modelling studies through the synergistic influence of Aspergillus and cellulose. J Environ Chem Eng. 2016;4:3193-3204. doi: 10.1016/j.jece.2016.06.027

5. UNEP, Clearing the water: A focus on water quality solutions. Nirobi, Kenya. 2010.

6. Narayan R, Meena RP, Patel AK, Prajapati AK, Srivastava $\mathrm{S}$, Mondal MK. Characterization and application of biomass gasifier waste material for adsorptive removal of $\mathrm{Cr}(\mathrm{VI})$ from aqueous solution. Environ Prog Sustainable Energy. 2016;35:95-102. doi: 10.1002/ ep.12205

7. Kanayochukwu Nduka J, ljeoma Kelle H. Onyenezi Amuka J. Health risk assessment of cadmium, chromium and nickel from car paint dust from used automobiles at auto-panel workshops in Nigeria. Toxicol Reports.2019;6:449-456. doi: 10.1016/j. toxrep.2019.05.007

8. Khare N, Bajpai J, Bajpai AK. Graphene Coated iron oxide (GCIO) nanoparticles as efficient adsorbent for removal of chromium ions: Preparation, characterization and batch adsorption studies. Environ Nanotechnol Monit Manage. 2018;10:148-162. doi: 10.1016/j. enmm.2018.06.002

9. Seraj, Mirzayi S, Nematollahzadeh B, Ali. Engineered maghemite nanoparticles with polyrhodanine for efficient removal of $\mathrm{Cr}(\mathrm{VI})$ from water. Environ Nanotechnol Monit Manage. 2018;10:94-103. doi: 10.1016/j.enmm.2018.05.009

10. Neto M, Bellato JO, Silva CR. Iron oxide/carbon nanotubes/chitosan magnetic composite film for chromium species removal. Chemosphere. 2019;218:391-401. doi: 10.1016/j. chemosphere.2018.11.080

11. Parka M, Parka J, Kangb J, Hanc YS, Jeonga HY. Removal of hexavalent chromium using mackinawite (FeS)coated sand. J Hazrd Mater. 2018;360:17-23. doi: 10.1016/j.jhazmat.2018.07.086

12. Chen Z, Huang Z, Cheng Y, et al. Cr(VI) uptake mechanism of Bacillus cereus. Chemosphere. 2012;87:211-216. doi: 10.1016/j.chemosphere.2011.12.050

13. Jeyasingh J, Philip L. Bioremediation of chromium contaminated soil: optimization of operating parameters under laboratory conditions. J Hazard
Mater. 2005;118(1-3):113-120. doi: 10.1016/j. jhazmat.2004.10.003

14. Rana P, Mohan N, Rajagopal C. Electrochemical removal of chromium from wastewater by using carbon aerogel electrodes. Water Res. 2004;38:28112820. doi: 10.1016/j.watres.2004.02.029

15. Wang L, Wang N, Zhu L, Yu H, Tang H. Photocatalytic reduction of $\mathrm{Cr}(\mathrm{VI})$ over different $\mathrm{TiO}_{2}$ photocatalysts and the effects of dissolved organic species. $J$ Hazard Mater. 2008;152:93-99. doi: 10.1016/j. jhazmat.2007.06.063

16. Imran M, Ahmad I, Barasubiye T, et al. Heavy metal tolerance among free-living fungi isolated from soil receiving long term application of wastewater. J Pure Appl Microbiol. 2020;14:157-170. doi: 10.22207/ JPAM.14.1.17

17. Mishra A, Saxena A, Surya Pratap Singh. Isolation and characterization of microbial strains from refinery effluent to screen their bioremediation potential. J Pure Appl Microbiol. 2019;13:2325-2332. doi: 10.22207/JPAM.13.4.48

18. Ackerley DF, Gonzalez CF, Park CH, Blake R, Keyhan $M$, Matin A. Chromate-reducing properties of soluble flavoproteins from Pseudomonas putida and Escherichia coli. Appl Environ Microbiol. 2004;70:873882. doi: 10.1128/AEM.70.2.873-882.2004

19. Brown SD, Thormpson MR, Verberkmoes NC, et al. Molecular dynamics of the Shewanella oneidensis response to chromate stress. Mol Cell Proteomics. 2006;5:1054-1071. doi: 10.1074/mcp.M500394MCP200

20. Sau G.B, Chatterjee S, Mukherjee SK. Chromate reduction by cell-free extract of Bacillus firmus KUCr1. Pol J Microbiol. 2010;59:185-190. doi: 10.33073/pjm2010-029

21. Srivastava S, Thakur IS. Evaluation of bioremediation and detoxification potentiality of Aspergillus Niger for removal of hexavalent chromium in soil microcosm. $J$ Soil Biol Biochem. 2006;38:1904-1911. doi: 10.1016/j. soilbio.2005.12.016

22. Carol D, Kingsley SJ, Vincent S. Hexavalent chromium removal from aqueous solutions by Pleurotus ostreatus spent biomass. Int J Eng Sci Technol. 2012;4:7-22.

23. Marzan LM, Hossain M, Mina SA, Akter Y, Chowdhury AMMA. Isolation and biochemical characterization of heavy-metal resistant bacteria from tannery effluent in Chittagong city, Bangladesh: Bioremediation viewpoint. Egypt J Aquat Res. 2017;43:65-74. doi: 10.1016/j.ejar.2016.11.002

24. Thacker U, Parikh R, Shouche $Y$, Madamwar D. Reduction of chromate by cell-free extract of Brucella sp. isolated from $\mathrm{Cr}(\mathrm{VI})$ contaminated sites. Bioresour Technol. 2007;98:1541-1547. doi: 10.1016/j. biortech.2006.06.011

25. Sonia S, Aparna D, Lal Gupta B, Gupta S. Optimization of cellulase production from bacteria isolated from soil. ISRN Biotechnol. 2013:985685. doi: 10.5402/2013/985685

26. Andro T, Chambost JP, Kotoujansky A, Cattano J, Barras F. Mutants of Erwinia chrysanthemi defective in secretion of pectinase and cellulose. J Bacteriol. 1984;160:1199-1203. doi: 10.1128/JB.160.3.1199- 


\subsection{4}

27. Rebecca LJ, Susithra G, Sharmila S, Merina PD. Isolation and screening of chitinase producing Serratio marcescens from soil. J Chem Pharm Res. 2013;5:192195.

28. Aneja KR. Experiments in Microbiology Plant Pathology and Biotechnology, $4^{\text {th }}$ edition, New Age International Publishers, New Delhi, India. 2003.

29. Bhattacharya S, Conolly RB, Kaminski NE, Thomas RS, Andersen ME, Zhang Q. A bistable switch underlying B-cell differentiation and its disruption by the environmental contaminant 2,3,7,8-tetrachlorodibenzo-p-dioxin. Toxicol Sci. 2010;115:51-65. doi: 10.1093/toxsci/kfq035

30. Gulati R, Saxena RK, Gupta R. A rapid plate assay for screening L-asparaginase producing microorganisms. Lett Appl Microbiol. 1997;24:23-26. doi: 10.1046/j.1472-765X.1997.00331.x

31. Sneath PHA, Mair NS, Sharpe ME, Holt JG. Bergey's Manual of Systematic Bacteriology. Williams and Wilkins, USA. 1986;2:1104-1139.

32. Osawa R, Walsh TP. Visual reading method for detection of bacterial tannase. Appl Environ Microbiol. 1993;18:74-78.

33. Shobana NS. Characterization of chromium bioremediation by Stenotrophomonas maltophilia SRS 05 isolated from tannery effluent. Int Res J Eng Technol. 2007;4:428-403

34. Essahale A, Malki M, Marin I, Moumni M. Hexavalent chromium reduction and accumulation by acinetobacter $\mathrm{AB} 1$ isolated from Fez tanneries in Morocco. Indian J Microbiol. 2012;52:48-53. doi: 10.1007/s12088-011-0187-1

35. Verma T, Singh N. Isolation and process parameter optimization of Brevibacterium casei for simultaneous bioremediation of hexavalent chromium and pentachlorophenol. J Basic Microbiol. 2012;52:1-13.

36. Pattanapipitpaisal P, Brown NL, Macaskie LE. Chromate reduction and $16 \mathrm{~S}$ rRNA identification of bacteria isolated from a $\mathrm{Cr}(\mathrm{VI})$-contaminated site. Appl Microbiol Biotechnol. 2001;57:257-261. doi: 10.1007/ s002530100758

37. Ayyasamy PM, Banuregha ER, Vivekanandhan EG, et al. Bioremediation of sago industry effluent and its impact on seed germination (green gram and maize). World J Microbiol Biotechnol. 2008;24:2677-2684. doi: 10.1007/s11274-008-9796-1

38. APHA, American public health association. Standard method for examination of water and wastewater. $21^{\text {st }}$ ed., Washington DC. 2005.

39. Saumya S, Yogesh Kumar S. Impact of arsenic toxicity on Black gram and its amelioration using phosphate. ISRN Toxicol. 2013;2013. doi: 10.1155/2013/340925

40. Steel R, Torrie JH. Principles and procedures of statistics. Mc Graw Hill Book Co. Inc., New York, 1992.

41. Liu YG, Xu WH, Zeng GM, Li X, Gao H. Cr(VI) reduction by Bacillus sp. isolated from chromium landfill. Process Biochem. 2006;41:1981-1986. doi: 10.1016/j. procbio.2006.04.020

42. Bae WC, Kang TG, Kang IK, Won YJ, Jeong BC. Reduction of hexavalent chromium by Escherichia coli ATCC 33456 in batch and continuous cultures. J Microbiol.
2000;38:36-39.

43. Poornima K, Karthik L, Swadhini SP, Mythili S, Sathiavelu A. Degradation of chromium by using a novel strains of Pseudomonas Species. J Microb Biochem Technol. 2010;2:095-099. doi: 10.4172/1948-5948.1000031

44. Murugavelh S, Mohanty K. Isolation, identification and characterization of $\mathrm{Cr}(\mathrm{VI})$ reducing Bacillus cereus from chromium contaminated soil. Chem Eng J. 2013;230:19. doi: 10.1016/j.cej.2013.06.049

45. Pal A, Paul AK. Aerobic chromate reduction by chromiumresistant bacteria isolated from serpentine soil. Microbiol Res. 2004;159:347-354. doi: 10.1016/j. micres.2004.08.001

46. Das S, Mishra J, Das SK, Pandey S. Investigation on mechanism of $\mathrm{Cr}(\mathrm{VI})$ reduction and removal by Bacillus amyloliquefaciens, a novel chromate tolerant bacterium isolated from chromite mine soil. Chemosphere. 2014;96;112-121. doi: 10.1016/j. chemosphere.2013.08.080

47. Tahri Joutey N, Sayel H, Bahafid W, Ghachtouli NE. Mechanisms of hexavalent chromium resistance and removal by microorganisms. Rev Environ Contam Toxicol. 2015;233:45-69. doi: 10.1007/978-3-31910479-9_2

48. Zakaria ZA, Zakaria Z, Surif S, Ahmad WA. Hexavalent chromium reduction by Acinetobacter haemolyticus isolated from heavy-metal contaminated wastewater. J Hazard Mater. 2007;146:30-38. doi: 10.1016/j. jhazmat.2006.11.052

49. RamaKrishna K, Philip L. Bioremediation of $\mathrm{Cr}(\mathrm{VI})$ in contaminated soils. J Hazard Mater. 2005;121:109117. doi: 10.1016/j.jhazmat.2005.01.018

50. Das AP, Mishra S. Biodegradation of metallic carcinogen hexavalent chromium $\mathrm{Cr}(\mathrm{VI})$ by an indigenously isolated bacterial strain. J Carcinog. 2010;9:1-6. doi: 10.4103/1477-3163.63584

51. Shaili S, Indu Shekhar T. Evaluation of biosorption potency of Acinetobacter sp. For removal of hexavalent chromium from tannery effluent. Biodegradation.2007;18:637-646. doi: 10.1007/ s10532-006-9096-0

52. Yakup AM, Gulay B, Meltem Y, Sema B, Omer G. Biosorption of $\mathrm{Hg}^{2+}, \mathrm{Cd}^{2+}$, and $\mathrm{Zn}^{2+}$ by Ca-alginate and immobilized wood-rotting fungus Funalia trogii. J Hazard Mater. 2004;109:191-199. doi: 10.1016/j. jhazmat.2004.03.017

53. Sarangi A, Krishnan C. Comparison of in vitro $\mathrm{Cr}(\mathrm{VI})$ reduction by CFEs of chromate resistant bacteria isolated from chromate contaminated soil. Bioresour Technol. 2008;99:4130-4137. doi: 10.1016/j. biortech.2007.08.059

54. Chatterjee S, Shekhawat K, Gupta N. Bioreduction of toxic hexavalent chromium by novel indigenous microbe Brevibacillus agri isolated from tannery wastewater. Int J Environ Sci Technol. 2018;16:35493556. doi: 10.1007/s13762-018-1885-6

55. Dixit S, Yadav A, Dwivedi PD, Das M. Toxic hazards of leather industry and technologies to combat threat: a review. J Cleaner Prod. 2015;87:39-49. doi: 10.1016/j. jclepro.2014.10.017

56. Saxena G, Chandra R, Bharagava RN. Environmental pollution, toxicity profile and treatment approaches 
for tannery wastewater and its chemical pollutants. Rev Environ Contam Toxicol. 2016;240:31-69. doi: 10.1007/398_2015_5009

57. Adamu A, Ijah UJ, Riskuwa ML, Ismail HY, Ibrahim UB. Isolation of biosurfactant producing bacteria from tannery effluents in Sokoto metropolis Nigeria. Int $J$ Innovative Sci Eng Technol. 2015;2:366-373.

58. Smitha HHS, Raghavendra MP, Shruthi S, Girish K. Bioremediation of rubber processing industry effluent by Arthrobacter sp. Int J Environ Sci Technol. 2012;2:3134.
59. Vijayanand S, Hemapriya J. Biosorption and detoxification of $\mathrm{Cr}(\mathrm{VI})$ by tannery effluent acclimatized halotolerant Bacterial Strain pv26. Int J Curr Microbiol App Sci. 2017;3:971-982.

60. Mythili K, Karthikeyan B. Bioremediation of tannery effluent and its impact on seed germination (blackgram and sunflower). Curr Bot. 2011;2:40-45.

61. Murkumar CV, Chauan PD. Influence of water pollution on germination of gram (Cicer arietinum L.) In: Current pollution Research in India. (Eds: Triveni pk., Goel PK), 1987. 